\title{
Information Systems Usage in Universities of Madhya Pradesh: An Empirical Investigation
}

\author{
Pranjal Muley and Nirmala Joshi
}

\begin{abstract}
The study attempted to determine the "Acceptance" of computer based Information Systems or Management Information Systems in the university staff members of cities of Madhya Pradesh. This was obtained on four indicators namely; 1) information systems/ Management information systems use by university staff members is the "Mandate"; 2) Dependency on information systems of university staff members; 3) Ease in work of university staff members by using Management Information system 4) Work preference by using MIS systems over manual way amongst university staff members. The study was descriptive with stratified sampling. Data collected from two state universities and two private universities.

Results indicated that university staff members were using information systems because of universities' mandate. They experienced ease in their daily work and thus developed dependency on these systems for obtaining all required data and information regarding their work. Results from Chi-Square tests indicated that there was significant difference found in opinion between state university staff members and private university staff members.
\end{abstract}

Index Terms-Acceptance, information systems, management information system. computer-based information systems.

\section{INTRODUCTION}

Modern Knowledge Societies, Knowledge is power and Data is money. Information is the key to any organization's sustenance and information management is one of the major activity amongst various activities [1].

Information Systems (IS) collects, processes, stores, analyse and disseminates data and information for a specific purpose. Ideally, an Information Systems comprised of: hardware, software, data, procedures, networks and people. They all are encompassed with technology. Another way to define the components of an Information System is through one-or-more smaller Information Systems. Especially, in large sized companies one sees large Information Systems being built by integrating two or more smaller systems. These smaller Information Systems are referred as 'Applications', and these were either computer programs/procedures/functions designed specifically to perform a specific or a set of tasks or business process.

Information is power. It drives commerce, protects nations, and forms the backbone of systems that range from health care to high finance [2]. In the business universe there are

Manuscript received April 16, 2020; revised July 2, 2020.

Pranjal Muley is with IT, VESIM Business School, Mumbai, India (e-mail: Pranjal.muley@ves.ac.in).

Nirmala Joshi is with MET's Institute of Management, Mumbai, India (e-mail: dr.nirmala.s.joshi@gmail.com). hundreds of applications designed for each of the functional areas.

The organisational setup of Higher Education System is comprised of a hierarchy of various authorities, committees and department, and people at different levels in the hierarchy have different needs vis-à-vis the information require to perform their designate job responsibilities and the decision-making associated with it. There are so many systems right from the academic management system, examination system, online learning systems, student information system, faculty information system etc. in universities. The basic idea behind all these systems are capturing the relevant data and representing \& visualizing them as required by different users [1].

The utilization of ICT for management of institutional power support is an important factor in the effectiveness of service management, and it seems to be a modern institution lifestyle that can be proud of in the community [3]-[5].

It has been observed that from last few decades, data in universities is exponentially growing, that created a need to use of ICT across all levels of management in universities irrespective of public or private. Various software can be used across university management levels. One of them is Decision Support System. Decision support systems are software based systems that supports business or organizational decision-making activities. Although they are mature technologies that have proven their usefulness in business, their use in academic environment is only in an incipient phase. A data driven decision support system for higher education could help universities to: [6].

- Understand recruitment trends and analyze the degree of success for its programs for attracting students

- Clarify student enrollment trends to different programs and asses the effectiveness of the courses offered

- Better track the financial transactions between students and university for a more efficient management of funds from tuition fees

- Disclose the right information, in the best possible manner, to government bodies in order to increase their comparative rankings, meet compliance requirements and secure the required funding level

- Synchronize marketing strategies with student feedback and take advantages from demographic, psychographic and geographic trends within student population

- Align student courses to labour market requirements in order to increase successful job placement upon graduation

- Offer to university decision makers the possibility to easily analyze operational data, from across faculties and functional areas

Higher education institutions continuously noticing a need of being equipped with some analytical capabilities due to 
ever increasing data of students and universities functions to analyse. However, some analytical capabilities are offered by current operational systems in the form of spreadsheet programs and other local functional software [7].

\section{CONCEPTUAL FRAMEWORK \& LITERATURE REVIEW}

In today's dynamic and digital environment where information technology is influencing all sectors of society. Higher education is not different. The technology acceptance model (TAM), proposed by Fred Davis (1985) in his doctoral thesis. His model suggested that system utilization could be explained by user motivation, which is directly influenced by an external stimulus consisting of the features and capabilities of the actual system [8]. However, several theories have been proposed in context with technology use and acceptance by users. These theories as a matter of fact were developed over the years and resulted from mutual extension. Some of them are The Theory of Reasoned Action (TRA); which was the extension of the Theory of Planned Behaviour (TPB). The Theory of Planned Behaviour is also derived from the Decomposed Theory of Planned Behaviour (DTPB). The Theory behind Technology Acceptance Model (TAM) has been derived from The Theory of Reasoned Action TRA [9]. The Technology Acceptance Model (TAM) has been applied to various disciplines of research. The Technology Acceptance Model (TAM) is a technology integration process developed by Davis (1989) that perceives the user to determine the behaviour in the technology utilization [10].

The growth and future of any organization whether a manufacturing unit, trading organization, business organization, service provider, government department or an educational institute depends on its resources and more so on their effective utilization. Every organization has plenty of data but they lack from relevant information required for making the decision [11]. Therefore, Information systems have become the backbone of most organizations. Banks could not process payments, governments could not collect taxes, hospitals could not treat patients, and supermarkets could not stock their shelves without the support of information systems.

According to Gupta, Kumar and Bhatnagar [1], in almost every sector education, finance, government, health care, manufacturing, and businesses large and small-information systems play a prominent role.

Tarafdar and Gordon [12] clearly indicated that Information systems have a key role in the development of organizations, enabling them to reduce costs, increase productivity, efficiency and effectiveness, improve both product and service quality, and optimize decision-making.

According to Karfaa et al [13], the development of MIS in any institution of higher learning is important for a modern management of the education systems. The development of MIS is not limited to creating a data and information system but more importantly, the development of a new management culture.

The utilization of information and communication technology (ICT) in education is an absolute necessity that must be undertaken and utilized by higher educations if they want to improve the quality of education [14]. This does not only serve to help management (supporter), but also serves to improve (enabler) in the decision-making process at various levels of college management [15].

According to Hanna [16], the effective utilization of information and communication technology in the management of education in higher educations will be realized when supported by the development of an effective management information system.

Guerrero C. and Sierra J. E. [17] explained that Institutions of Higher Education require Information Systems in real time, which provide reliable information to increase the strategic performance in management and decision making.

Martins et al [18] described that the use of online platforms allows students to have a high degree of freedom in managing their time by allowing registration, access to content and other information regarding the courses remotely. They also recommended Education institutions to continuously increase the level and density of business knowledge in order to take business decisions that allow maintaining their competitiveness.

Surej P. [19] developed a conceptual model to explore the critical success factors towards adoption of Information Technology by faculty in Higher Education. In this study he found that factors viz Self-efficacy, relative perceived ease of use, compatibility and previous computer experience are directly proportional to perceived ease of use and attitude towards using technologies.

Martins et al [15] described that the continuous use of dynamic and disruptive ICT as energizing elements of the educational process is a reality of current days. The success of any Educational Management Information System depends on the fact that education institutions must safeguard that their education management information systems are of high quality and students are quite satisfied with the system and information received from it and so engage in continuous use.

On the basis of review of literature, it was observed that most of the researchers had focused on the usage of information systems from management perspective to study the cost benefit, efficiency improvement. This study is unique in the way that it is conducted to determine the overall approach of university staff members towards information systems in tier-2 cities of India.

\section{OBJECTIVES OF THE STUDY}

The main objective of undertaking the study was to gain an insight about the "Acceptance" for various prevailing Information Technology and software applications (Information Systems), currently used by staff members at the State and private universities of Madhya Pradesh. The present study covers the current use of "Information Systems" in carrying out various administrative tasks across universities and tries to examine whether university staff members are relying on these information systems for carrying out their jobs or preferring to continue old manual way of working. To carry out the study, Indicator questions have been framed in order to infer whether staff members across State-owned and Private Universities have accepted IT and MIS or not. 


\section{HYPOTHESES}

The study considers universities, irrespective of their types, as significant elements for IT and MIS acceptance. Null hypotheses have been framed to test the correspondent significance.

\section{Hypothesis-1}

H0: There is no significant difference between staff members of DAVV and ITM universities for Acceptance of computer-based Information Systems.

\section{Hypothesis-2}

H0: There is no significant difference between staff members of DAVV and JIWAJI universities for Acceptance of computer-based Information Systems.

\section{Hypothesis-3}

H0: There is no significant difference between staff members of JIWAJI and ITM universities for Acceptance of computer-based Information Systems

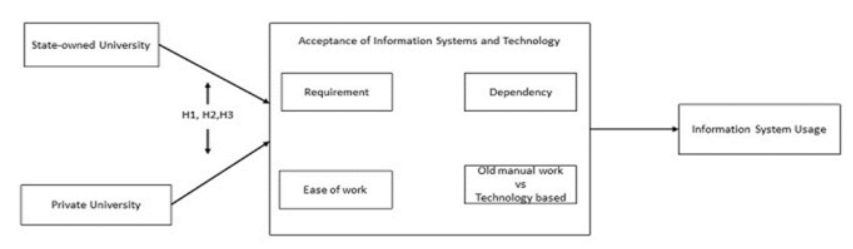

Fig. 1. Hypothesis framework.

\section{Research Methodology}

\section{A. Data Collection Procedure}

The study is based on primary data that was collected from state-owned and private universities of Madhya Pradesh. Three state universities, namely DAVV, Jiwaji University and Mahakal University, and two private universities ITM and Amity University were studied as sample. But relevant structured data of three universities used in this paper and remaining unstructured information used to authenticate the findings. Data were collected through questionnaire and personal interview. Stratified purposive sampling method was used while selecting respondents.

The other sources for data collection were books and journals, online journals articles and internet. That provided valuable supporting data. The data were collected by sending emails, direct interviews and through questionnaire. The study is longitudinal and was conducted during the period from May - July 2016.

\section{B. Sample}

The objective of the study is to know Information System acceptance and their usage among the state- owned and private universities' staff members. For the study, 2 private and 3 state owned universities of Madhya Pradesh region were taken. The sample size for the study undertaken was 58 respondents across private and State universities of the state.

\section{Method}

The data has been analysed by using SPSS 16 and MS Excel 10. Since the data was non-normally distributed. Hence Mann Whitney U-test and Kruskel Wallis non-parametric tests were used to test the hypotheses.

\section{DATA ANALYSIS AND RESUlts}

This part of the study consists of data analysis and findings. The study uses MS-Excel version 10 and SPSS version 16 to analyse data. Data Analysis has been done in two parts. Part-1 consists of Comparative Analysis, where, responses for individual question were analysed using Kruskal-Walis $\mathrm{H}$ Test. Part-2 consists of testing null hypotheses using Mann-Whitney U test.

\section{A. Part-1}

In this section of the study, each individual indicator question was analysed using Kruskal-Walis H Test.

\section{Question 1 (Analysis):}

TABLE I: ACCEPTANCE OF COMPUTER BASED INFORMATION SYSTEMS (RANKS)

\begin{tabular}{|l|l|c|c|}
\hline \multicolumn{2}{|c|}{ (RANKS) } \\
\hline $\begin{array}{l}\text { University needs } \\
\text { me to use this MIS } \\
\text { software }\end{array}$ & University & N & Mean Rank \\
\hline & 24 & 24.29 \\
\hline & JIWAJI & 14 & 17.00 \\
\hline & ITM & 20 & 44.50 \\
\hline & Total & 58 & \\
\hline
\end{tabular}

TABLE II: ACCEPTANCE OF COMPUTER BASED INFORMATION SYSTEMS (TEST STATISTICS)

\begin{tabular}{|l|l|}
\hline & University needs me to use this MIS software \\
\hline Chi-Square & 29.542 \\
\hline Df & 2 \\
\hline Asymp. Sig. & .000 \\
\hline
\end{tabular}

From the Table I, it is seen that Mean Ranks for DAVV, JIWAJI and ITM universities are 24.29, 17.00, and 44.50 subsequently. From the Table II, Chi-Square $(\chi 2)$ test shows value of $p=0.000$. Therefore it can be inferred that there is significant difference in opinion amongst the staff members of three universities whether working on computer-based Information System is a mandate.

\section{Question 2 (Analysis):}

TABLE III: ACCEPTANCE OF COMPUTER BASED INFORMATION SYSTEMS (RANKS)

\begin{tabular}{|l|l|l|l|}
\hline & University & $\mathrm{N}$ & Mean Rank \\
\hline I have to depend & DAVV & 21 & 36.90 \\
\cline { 2 - 4 } on MIS software & JIWAJI & 14 & 34.50 \\
\cline { 2 - 4 } $\begin{array}{l}\text { totally for any } \\
\text { data or report }\end{array}$ & ITM & 20 & 14.10 \\
\cline { 2 - 4 } & Total & 55 & \\
\hline
\end{tabular}

TABLE IV: ACCEPTANCE OF COMPUTER BASED INFORMATION SYSTEMS (TEST STATISTICS)

\begin{tabular}{|l|l|}
\hline & $\begin{array}{l}\text { I have to depend on MIS software } \\
\text { totally for any data or report }\end{array}$ \\
\hline Chi-Square & 28.906 \\
\hline Df & 2 \\
\hline Asymp. Sig. & .000 \\
\hline
\end{tabular}

From the Table III, Mean Ranks for DAVV, JIWAJI and ITM universities are shown $36.90,34.50$ and 14.10 subsequently. From Chi-Square (Table IV) test, it can be inferred that there is a significant difference in opinions amongst the staff members of three universities about dependency on computer-based Information Systems for any data or report system. 


\section{Question 3 (Analysis):}

TABLE V: ACCEPTANCE OF COMPUTER BASED INFORMATION SYSTEMS (RANKS)

\begin{tabular}{|l|l|l|l|}
\hline & University & N & Mean Rank \\
\hline \multirow{2}{*}{$\begin{array}{l}\text { MIS software } \\
\text { makes works }\end{array}$} & DAVV & 24 & 36.50 \\
\cline { 2 - 4 } & JIWAJI & 14 & 29.36 \\
\cline { 2 - 4 } & ITM & 20 & 21.20 \\
\cline { 2 - 4 } & Total & 58 & \\
\hline
\end{tabular}

TABLE VI: ACCEPTANCE OF COMPUTER BASED INFORMATION SYSTEMS (TEST STATISTICS)

\begin{tabular}{|l|l|}
\hline \multicolumn{2}{l}{ (TEST STATISTICS) } \\
\hline Chi-Square & MIS software makes works easy \\
\hline Df & 25.956 \\
\hline Asymp. Sig. & .000 \\
\hline
\end{tabular}

Mean Ranks (Table V) for DAVV, JIWAJI and ITM universities are shown 36.50, 29.36, 21.20 respectively whereas Chi-Square (Table VI) test evaluates value 15.956 and $\mathrm{p}=0.000$. Therefore, it can be inferred that here is a significant difference in opinions amongst staff members of the three universities about work easiness by using computer-based information systems.

\section{B. Part-2}

Data analysis in this part is done by using Mann-Whitney $\mathrm{U}$ test to test the null hypotheses, that have been framed to find out the difference among universities for "Acceptance" of Computer-based Information Systems.

\section{Hypothesis-1}

H0: There is no significant difference between staff members of DAVV and ITM universities for Acceptance of Information Systems.

TABLE VII: RESULT INTERPRETATION OF HYPOTHESIS-1 (RANKS)

\begin{tabular}{|l|l|l|l|}
\hline & University & N & Mean Rank \\
\hline Acceptance_MIS & DAVV & 24 & 18.67 \\
\cline { 2 - 4 } & ITM & 20 & 27.10 \\
\cline { 2 - 4 } & Total & 44 & \\
\hline
\end{tabular}

Mean Ranks (Table VII) for "Acceptance of MIS" are 18.67 for DAVV and 27.10 for ITM university respectively, which reveals that acceptance towards computer-based information systems is higher in ITM university staff members. Value of Mann-Whitney U test (Table VIII) is 148.000 and p- value is 0.026 . Hence, Null hypothesis is not accepted.

Therefore, it can inferred that there is significant difference between staff members of DAVV and ITM universities for Accepting computer-based Information Systems in their working.

TABLE VIII: RESULT INTERPRETATION OF HYPOTHESIS-1 (TEST

\begin{tabular}{|l|l|}
\multicolumn{2}{l}{ STATISTICS) } \\
\hline & Acceptance_MIS \\
\hline Mann-Whitney U & 148.000 \\
\hline Wilcoxon W & 448.000 \\
\hline Z & -2.220 \\
\hline Asymp. Sig. 2- tailed) & .026 \\
\hline
\end{tabular}

\section{Hypothesis-2}

H0: There is no significant difference between staff members of DAVV and JIWAJI universities for Acceptance of Information Systems, Importance, Awareness and Satisfaction.
TABLE IX: RESULT INTERPRETATION OF HYPOTHESIS-2 (RANKS)

\begin{tabular}{|l|l|l|l|}
\hline & University & N & Mean Rank \\
\hline Acceptance_MIS & DAVV & 24 & 20.54 \\
\cline { 2 - 4 } & JIWAJI & 14 & 17.71 \\
\cline { 2 - 4 } & Total & 38 & \\
\hline
\end{tabular}

From the Table IX, it is shown that the Mean Ranks "Acceptance of MIS" are 20.54 and 17.71 for JIWAJI and DAVV universities subsequently which reveals that acceptance for computer-based information system is a bit more in staff members of DAVV university than staff members of Jiwaji university. Besides this, results of Mann-Whitney U test (Table X) shows p-value as 0.417. Since $\mathrm{p}$-values is greater than 0.05 , therefore, Null hypothesis is accepted. Therefore, It can collectively be inferred that "Acceptance" of Information Systems in the staff members of DAVV and JIWAJI is more or less the same.

TABLE X: RESULT INTERPRETATION OF HYPOTHESIS-2 (TEST STATISTICS)

\begin{tabular}{|l|l|}
\hline & Acceptance_MIS \\
\hline Mann-Whitney U & 143.000 \\
\hline Wilcoxon W & 248.000 \\
\hline Z & -.812 \\
\hline Asymp. Sig. (2- tailed) & .417 \\
\hline Exact Sig. [2*(1-tailed Sig.)] & $.463 \mathrm{a}$ \\
\hline
\end{tabular}

\section{Hypothesis-3}

H0: There is no significant difference between staff members of JIWAJI and ITM universities for Acceptance of Information Systems, Importance, Awareness and Satisfaction.

TABLE XI: RESULT INTERPRETATION OF HYPOTHESIS-3 (RANKS)

\begin{tabular}{|l|l|l|l|}
\hline & University & N & Mean Rank \\
\hline Acceptance_MIS & JIWAJI & 14 & 12.79 \\
\cline { 2 - 4 } & ITM & 20 & 20.80 \\
\cline { 2 - 4 } & Total & 34 & \\
\hline
\end{tabular}

Mean Ranks (Table XI) for "Acceptance of MIS" are 12.79 for JIWAJI and 20.88 for ITM universities which clearly show that the Acceptance for computer-based information systems are more in ITM than JIWAJI University. Whereas, Mann-Whitney U test (Table XII) shows that $\mathrm{p}$-value as 0.017 . Since it is less than 0.05 . Hence, the Null hypothesis is not accepted.

Therefore, it can be inferred that there is statistically significant difference between staff members of JIWAJI and ITM universities for Accepting computer- based information systems.

TABLE XII: RESUlT INTERPRETATION OF HYPOTHESIS-3 (TEST STATISTICS)

\begin{tabular}{|l|l|}
\hline & Acceptance_MIS \\
\hline Mann-Whitney U & 74.000 \\
\hline Wilcoxon W & 179.000 \\
\hline $\mathrm{Z}$ & -2.384 \\
\hline Asymp. Sig. (2- tailed) & .017 \\
\hline Exact Sig. [2*(1-tailed Sig.)] & $.020 \mathrm{a}$ \\
\hline
\end{tabular}

\section{CONCLUSION}

The objective of the study was to find out the Acquisition/ Acceptance of computer based Information Systems or Management Information Systems in the university staff members of cities of Madhya Pradesh which determines the 
overall information system and technology usage in universities. The study observed that universities wanted their employees to use computer-based Information Systems in their daily routine for gathering, processing data and creating reports irrespective of their "Will". The study also observed that the university staff members realized that these Information Systems were assisting them to smoothly carry out their day-to-day operations. However there is a significant difference in opinions in staff members of state-owned and private universities. It was found that staff members of private universities were more adapted to computer-based information systems than state-owned universities.

\section{LIMITATION OF THE STUDY AND FUTURE SCOPE}

Like other studies, this study also has some limitations. The results revealed from the present study might not be applicable to other universities. The results are constricted to the sample units only collected during the study. The present study considers only few state owned and private universities of Madhya Pradesh. The interpretation is based on data received; thus study might be affected by respondents' biases The findings of the study are based on three universities; the larger sample size would get more wildly acceptable results. Only one state has been considered in terms of universities under the study. Future studies can be conducted by collecting data from state and private universities of different state to determine the same.

\section{APPENDIX}

Abbreviation used: DAVV: Devi Ahilya Vishwa Vidyalaya, Indore; MIS: Management Information system; IT: Information Technology; ITM: ITM university, Gwalior; JIWAJI: Jiwaji university, Gwalior.

\section{CONFLICT OF INTEREST}

We, the authors, herewith declare that the submitted work has been submitted without conflict of interest. The submitted work does not include any personal, professional or financial relationship.

\section{AUTHOR CONTRIBUTIONS}

Both the authors have equal contribution in the submitted research. Dr. Pranjal Muley initiated the research, did the literature review, developed questionnaire, collected data and write the research article.

Dr. Nirmala Joshi developed the conceptual framework of the research, framed objectives and hypotheses and analysed the data.

\section{REFERENCES}

[1] S. Gupta, A. Kumar, and R. Bhatnagar, "Role of information systems in a University setup -A case study," International Journal of Computer Science and Electronics Engineering, vol. 4, issue 3, pp. 2320-4028, 2016.

[2] D. Sarokin and J. Schulkin. (2016). Missed Information. [Online]. Available: https://mitpress.mit.edu/books/missed-information

[3] D. K. Allen and N. Fifield, "Re-engineering change in higher education," Information Research, vol. 4, no. 3, 1999.

[4] J. O'Brien, Introduction to Information System, 12th ed. Singapore: McGraw Hill, 2005.
[5] J. Kettunen, "Management information system in higher education," IGI Global, pp. 542-546, 2008

[6] J. Lachlan. (2013). Universities: Competing through business intelligence and analytics. [Online]. Available: http://www.yellowfinbi.com/YFCommunityNews-Universities-Comp eting-through-Business-Intelligence-and-analytics-147594

[7] V. Gorgan, "Requirement analysis for a higher education decision support system. Evidence from a Romanian university," Procedia Social and Behavioral Sciences, vol. 197, pp. 450-455, 2015.

[8] M. Vuković, S. Pivac, and D. Kundid, "Technology acceptance model for the internet banking acceptance in split," Business Systems Research, vol. 10, no. 2, 2019.

[9] A. M. Momani and M. M. Jamous, "The evolution of technology acceptance theories," International Journal of Contemporary Computer Research, vol. 1, issue 1, 2017.

[10] D. Yuniarto, M. A. Helmiawan, and E. Firmansyah, "Technology acceptance in augmented reality," Journal Online Informatika, vol. 3, no. $1,2018$.

[11] H. Aldarbesti and J. P. Saxena, "Management information system for education," IOSR Journal of Research \& Method in Education, vol. 4, issue 1, pp. 36-44, 2015.

[12] M. Tarafdar and S. R. Gordon, "Understanding the influence of information systems competencies on process innovation: A resource-based view," The Journal of Strategic Information Systems, vol. 16, issue 4, pp. 353- 392, 2007.

[13] Y. M. Karfaa, H. B. Sulaiman, and S. Yussof, "Management information systems for supporting educational organizations: A case study through one private university in Malaysia," International Journal of Scientific and Research Publications, vol. 5, issue 10, 2015.

[14] E. Indrayani, "Management of academic information system (AIS) at higher education in the city of Bandung," Procedia - Social and Behavioral Sciences, vol. 103, pp. 628-636, 2013.

[15] R. E. Indrajit and R. D. Jokopranoto, "Management perguruan tinggi modern," Penerbit And Jogjakarta, USA: IT Govenment Institute, 2006.

[16] D. E. Hanna, "Building a leadership vision: Eleven strategic challenges for higher education," Educause Review, vol. 38, no. 4, 2003.

[17] C. Guerrero and J. E. Sierra, "Impact of the implementation of a new information system in the management of higher education institutions," International Journal of Applied Engineering Research, vol. 13, no. 5, pp. 2523-2532, 2018.

[18] J. Martins, F. Brancoa, R. Gonçalvesa, M. Au-Yong-Oliveirac, T. Oliveirad, M. Naranjo-Zolotovd, and F. Cruz-Jesusd, "Assessing the success behind the use of education management information systems in higher education," Telematics and Informatics, vol. 38, pp. 182-193, 2019.

[19] S. P. John, "The integration of information technology in higher education: A study of faculty's attitude towards IT adoption in the teaching process," Contaduríay Administración, vol. 60, pp 230-252, 2015 .

Copyright (C) 2020 by the authors. This is an open access article distributed under the Creative Commons Attribution License which permits unrestricted use, distribution, and reproduction in any medium, provided the original work is properly cited (CC BY 4.0)

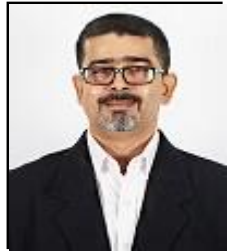

Pranjal Muley is a Ph.D and MBA in information systems. He is currently working as an associate dean of information technology. He has taught a many MBA and MCA students. His area of working is data science and analytics practices in higher education.

He has attended many conferences and workshops. $\mathrm{He}$ has been a part of international business analytics conference.

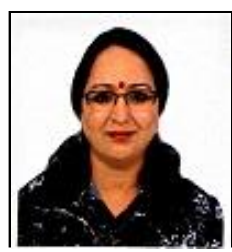

Nirmala Joshi is a $\mathrm{Ph} . \mathrm{D}$ and research guide. She was amongst the Top- 25 meritorious students of the Rajasthan Board at the SSC and HSC exams (in 1985 and 1986). She topped the ranking at the Jodhpur University consecutively in her B.Com and M.Com exams in 1989 and 1991.

In 1991, as the first candidate to clear NET-JRF prior to the final exams of Masters Course, her achievement was applauded at the national level. She became the youngest $\mathrm{Ph}$. D degree holder in the whole of Rajasthan, a rare achievement that added to the pride of Jodhpur University in 1995. She authored the book, "International Finance" and "Cost \& Management Accounting" for Management finance students. 